\title{
Multiple magma degassing sources at an explosive volcano
}

\author{
Roberto Moretti $^{\mathrm{a}, \mathrm{b}, *}$, Ilenia Arienzo ${ }^{\mathrm{b}}$, Lucia Civetta ${ }^{\mathrm{c}, \mathrm{b}}$, Giovanni Orsi ${ }^{\mathrm{b}}$, Paolo Papale ${ }^{\mathrm{d}}$ \\ a Dipartimento di Ingegneria Civile, Design. Edilizia e Ambiente, Seconda Università di Napoli, Via Roma, 29, 81031 Aversa (CE), Italy \\ ${ }^{\mathrm{b}}$ Istituto Nazionale di Geofisica e Vulcanologia, Sezione Osservatorio Vesuviano, Via Diocleziano 328, 80124 Napoli, Italy \\ ' Dipartimento di Scienze della Terra, Ambiente e Risorse, Università di Napoli "Federico II", Largo San Marcellino, 80100 Napoli, Italy \\ ${ }^{\mathrm{d}}$ Istituto Nazionale di Geofisica e Vulcanologia, Sezione di Pisa, Via della Faggiola 32, 53126 Pisa, Italy
}

\section{A R T I C L E I N F O}

\section{Article history:}

Received 14 September 2012

Received in revised form

11 February 2013

Accepted 13 February 2013

Editor: B. Marty

\section{Keywords:}

magmatic degassing

hydrothermal systems

explosive volcanism

unrest

isotopic inversion

fluxing

\begin{abstract}
A B S T R A C T
Persistent degassing of closed-conduit explosive volcanoes may be used to inspect and monitor magmatic processes. After interaction with shallow hydrothermal fluids, volcanic gases collected at surface can differ substantially from those exsolved from magma. We report here on an innovative approach to identify and separate the contribution of variable magmatic components from fumarolic gases, by processing the 30-year-long geochemical dataset from the Campi Flegrei caldera, Southern Italy. The geochemical record shows periodic variations, which are well correlated with geophysical signals. Such variations are interpreted as due to the time-varying interplay of two magma degassing sources, each differing in size, depth, composition, and cooling/crystallization histories. Similar multiple degassing sources are common at explosive volcanoes, with frequent ascent and intrusion of small magma batches. Our innovative method permits the identification of those magma batches, which contributes to the interpretation of unrest signals, forecasting and assessment of volcanic hazards.
\end{abstract}

(c) 2013 Elsevier B.V. All rights reserved.

\section{Introduction}

Magmas contain variable amounts of volatile components, which can exsolve in a separate gas phase upon their decompression during ascent and/or crystallization. Both processes depend on bulk magma chemistry, temperature, and rheology (e.g., Parfitt and Wilson, 2008); therefore, volcanic gas compositions can, in principle, be inverted to quantify physical and chemical parameters of the degassing magma. Gas plumes at open conduit volcanoes are directly related to magma degassing within the volcanic system, allowing therefore a straightforward use of the gas composition to track evolution of the magmatic system (Aiuppa et al., 2010, 2007). On the contrary, gases released at closed conduit volcanoes, usually associated with explosive eruptions, have to rise through cold, permeable and fractured rocks that usually host hydrothermal fluids (Giggenbach, 1996, 1987). In such cases, volcanic gases that reach the surface result from chemical reactions, heat transfer and mixing between magmatic and hydrothermal components. Under such circumstances, retrieving information on the deep magmatic components can be extremely complex, and generates ambiguities when interpreting variations in the degassing patterns recorded at the surface (e.g., Chiodini et al., 2006).

\footnotetext{
* Corresponding author at: Dipartimento di Ingegneria Civile, Design. Edilizia e Ambiente, Seconda Università di Napoli, Via Roma, 29, 81031 Aversa (CE), Italy. Tel./fax: + 390815010416

E-mail addresses: roberto.moretti@ov.ingv.it, roberto.moretti@unina2.it (R. Moretti).
}

We have developed a general method for exploring the relationships between magmatic and hydrothermal components and assessing their relative contributions to the gases discharged at closed-conduit explosive volcanoes. Our method combines long geochemical records with highly accurate oxygen isotopic data and multi-component gas-melt equilibrium modelling. The database is represented by the 30-year-long record of accurate chemical and isotopic data on fumarolic effluents (Chiodini et al., 2011, 2010a) of the Solfatara crater from the restless Campi Flegrei caldera (CFc) (Orsi et al., 1999, 1996). The CFc system has been deeply investigated and monitored for decades because of its very high volcanic risk (Orsi et al., 2009, 2004; Selva et al., 2012), providing a detailed reconstruction of the volcanic and deformation history over the last tens of thousands of years (Orsi et al., 2009, 1996), as well as petrologically- and geophysicallyconsistent pictures of both architecture and evolution of the magmatic feeding system (Arienzo et al., 2010; Di Renzo et al., 2011; Mangiacapra et al., 2008).

Application of the method shows that the recorded chemical variations reflect changes occurring in the magmatic gas component, and result from the interplay of two degassing sources that differ in depth, size, and crystallization time-scale. This conclusion provides a consistent and robust scenario that can be generalized to other closed-conduit volcanoes. According to this scenario, rise, emplacement at shallow depth, and cooling of a small magma batch is a short-term tuning effect over a long-term degassing trend imposed by a large, deep, and long-lived reservoir from which the small magma batch separated. 


\section{Data analysis}

Fumarolic gases (below with subscript "f") from the Solfatara crater at $\mathrm{CFc}$ are about $99 \% \mathrm{H}_{2} \mathrm{O}, \mathrm{CO}_{2}$ and $\mathrm{H}_{2} \mathrm{~S}$, plus minor amounts of $\mathrm{H}_{2}, \mathrm{CO}, \mathrm{CH}_{4}$. Previous investigation demonstrated that the fumarolic emissions at CFc are fed by a nearly monophasic and uncondensing gas plume that separates from the deepest $(2-2.5 \mathrm{~km})$ and hottest portion of the hydrothermal system, the latter interacting with ascending magmatic gases at conditions close to the $\mathrm{H}_{2} \mathrm{O}$ critical point (Caliro et al., 2007). Such interaction is so profound that acid species in the magmatic gases, like $\mathrm{HCl}, \mathrm{HF}$ and $\mathrm{SO}_{2}$, are completely scrubbed (Symonds et al., 1991).

Gas species concentrations at Solfatara crater display oscillations that have been related to discrete pulses of deep magmatic gas mixing with hydrothermal fluids (Chiodini et al., 2010a; D'Auria et al., 2011; Gottsmann et al., 2006; Todesco and Berrino, 2005). $\mathrm{H}_{2} \mathrm{O}_{(\mathrm{f})} / \mathrm{CO}_{2(\mathrm{f})}$ ratios display minima (Fig. 1a) reflecting periods of an increased contribution of a $\mathrm{CO}_{2}$-rich magmatic gas (Caliro et al., 2007; Chiodini et al., 2010a; D'Auria et al., 2011).

The corresponding variation of $\mathrm{CH}_{4(\mathrm{f})} / \mathrm{CO}_{2(\mathrm{f})}$ ratios (Fig. 1b), which are unaffected by $\mathrm{H}_{2} \mathrm{O}$ condensation, testifies that large amounts of oxidized magmatic fluids episodically enter, dilute and pressurize the hydrothermal system, inhibiting $\mathrm{CH}_{4}$ formation (Chiodini et al., 2010a). Ingression of magmatic fluids in the hydrothermal system can also be tracked from the $\mathrm{H}_{2} \mathrm{~S}_{(\mathrm{f})} / \mathrm{CO}_{2(\mathrm{f})}$ ratio (Fig. 1c). Because $\mathrm{H}_{2} \mathrm{~S}_{(\mathrm{f})}$ is generally fixed by equilibrium with hydrothermal pyrite, fluctuations of such a ratio depend on (1) variations in $\mathrm{CO}_{2}$ partial pressure $\left(P_{\mathrm{CO}_{2}}\right)$ imposed, still at equilibrium with pyrite, by the proportion of magmatic and hydrothermal components in the fumarolic gases (Chiodini et al., 2010b), and (2) perturbations of the equilibrium with hydrothermal pyrite. When $\mathrm{CO}_{2}$-rich, hot and oxidized magmatic fluids enter the hydrothermal system, $\mathrm{CH}_{4(\mathrm{f})} / \mathrm{CO}_{2(\mathrm{f})}$ and $\mathrm{H}_{2} \mathrm{~S}_{(\mathrm{f})} / \mathrm{CO}_{2(\mathrm{f})}$ ratios are expected to reach minimum values (Fig. 1). All these minima are usually not synchronous, reflecting different mobility and interaction mechanisms of the variable gas species in the hydrothermal system (Chiodini et al., 2010a; Todesco and Berrino, 2005).

Despite temporal gaps prior to 1998, oxygen isotopes $\left(\delta^{18} \mathrm{O}_{\mathrm{H}_{2} \mathrm{O}(\mathrm{f})}\right)$ of fumarolic steam condensates have been almost stable except the period around 1985 when a short-term dipping was observed and around June 2000, when they peaked at around $-0.5 \%$ (BG and BN), before declining to $-2 \%$ in 2007 (Fig. 1d), and do not show appreciable similarity with the other geochemical indicators, despite a peak in $\delta^{18} \mathrm{O}_{\mathrm{H}_{2} \mathrm{O}(\mathrm{f})}$ value being observed in year 2000 in correspondence with minimum $\mathrm{CO}_{2(\mathrm{f})}$ contents. It is worth noting that Pisciarelli datapoints plot at $\delta^{18} \mathrm{O}_{\mathrm{H}_{2} \mathrm{O}(\mathrm{f})}$ values lower than Bocca Grande and Bocca Nuova ones, compatibly with the different outlet temperature of fumaroles (Fig. 1d).

A time correspondence exists between maxima and minima in $\mathrm{H}_{2} \mathrm{O}_{(\mathrm{f})} / \mathrm{CO}_{2(\mathrm{f})}, \mathrm{CH}_{4(\mathrm{f})} / \mathrm{CO}_{2(\mathrm{f})}, \mathrm{H}_{2} \mathrm{~S}_{(\mathrm{f})} / \mathrm{CO}_{2(\mathrm{f})}$ gas ratios and ground deformation residuals (Fig. 1a-e). Moreover, after year 2000 both ground deformation residual and geochemical indicators show nearly monotonic trends. Seismicity occurs (i) during the 1982-84 uplift, with activity lasting till 1985, (ii) in correspondence with the maxima in ground deformation residuals $(1989,1994,2000)$ and (iii) after 2005 , with a long-lasting activity which follows the aforementioned nearly monotonic behaviour (Fig. 1f). These elements suggest a causal relationship between deep degassing and geophysical observables (Chiodini et al., 2011, 2010a; D'Auria et al., 2011, 2012; Gottsmann et al., 2006; Todesco and Berrino, 2005; Todesco et al., 2010).

Since year 2000 the geochemical trends at fumaroles show remarkable differences from the preceding two decades (Chiodini et al., 2010a,b). While the period 1982-2000 was characterized by oscillations, post-2000 trends correspond to a substantially continuous increase in $\mathrm{CO}_{2}$ relative to $\mathrm{H}_{2} \mathrm{O}$ and $\mathrm{S}$ contents. From 2010, $\mathrm{H}_{2} \mathrm{O}_{\text {(f) }} / \mathrm{CO}_{2(\mathrm{f})}$ ratio appears to have attained a stable value around 3.3 (Fig. 1a).

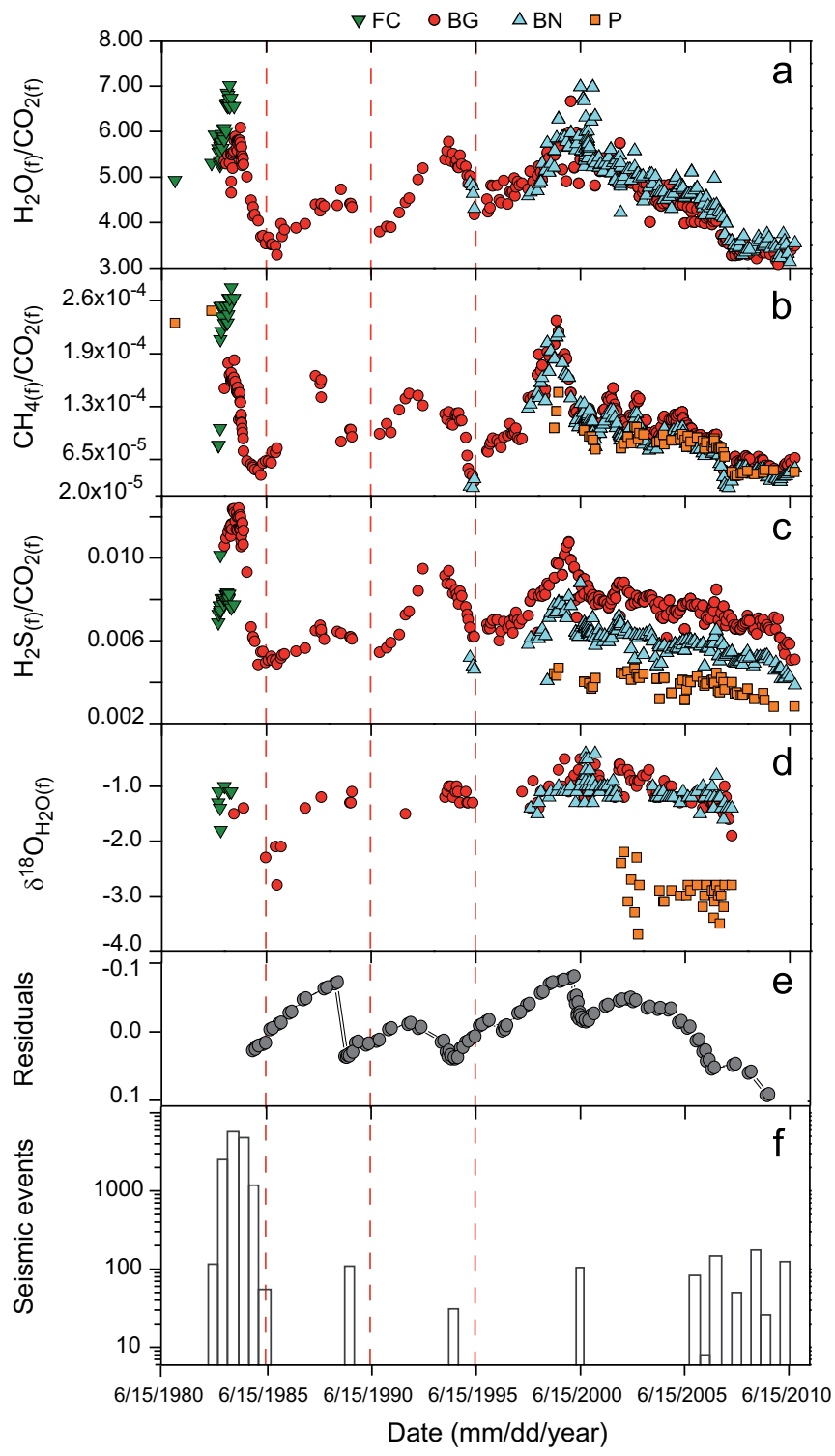

Fig. 1. Chronograms of relevant geochemical and geophysical observables. Molar $\mathrm{H}_{2} \mathrm{O}_{(\mathrm{f})} / \mathrm{CO}_{2(\mathrm{f})}$ (panel a), $\mathrm{CH}_{4(\mathrm{f})} / \mathrm{CO}_{2(\mathrm{f})}$ (panel b), $\mathrm{H}_{2} \mathrm{~S}_{(\mathrm{f})} / \mathrm{CO}_{2(\mathrm{f})}$ (panel c) ratios and $\delta^{18} \mathrm{O}_{\mathrm{H}_{2} \mathrm{O}, \mathrm{f}}$ values (panel d) have been determined on Solfatara fumarolic discharges (Caliro et al., 2007; Chiodini et al., 2011, 2010a) (FC: Fumarola Centrale; BG: Bocca Grande; BN: Bocca Nuova; P: Pisciarelli). Panels (e) and (f) show chronograms of ground elevation residuals (computed after addition of the secular subsidence and subtraction of a first-order exponential decay in time; Chiodini et al., 2010a), and seismicity (D'Auria et al., 2011), respectively. Note that ground elevation residuals are shown on a reversed axis to remark the strong correlation with $\mathrm{CH}_{4(\mathrm{f})} / \mathrm{CO}_{2(\mathrm{f})}$ the minima of which are anticipated by seismicity.

\section{Methods and calculation}

Based on the guidelines of Caliro et al. (2007), $\delta^{18} \mathrm{O}_{\mathrm{H}_{2} \mathrm{O}(\mathrm{f})}$ data (Fig. 1d) are used in the frame of a refined inversion that yields the magmatic gas fraction mixing with the hydrothermal fluid, and the concentration of magmatic $\mathrm{H}_{2} \mathrm{O}$ and $\mathrm{CO}_{2}$. These will be used to track the patterns of magma degassing and constrain the degree of magma differentiation, by using thermodynamic tools for gas-melt equilibria.

\subsection{Isotopic inversion}

${ }^{18} \mathrm{O}$ fractionation between $\mathrm{H}_{2} \mathrm{O}$ and $\mathrm{CO}_{2}$ heavily affects isotopic gas composition, also in relatively low temperature discharges, 
such as Solfatara fumaroles $\left(95-162^{\circ} \mathrm{C}\right.$ ) (Chiodini et al., 2000; Richet et al., 1977). However, the $\delta^{18} \mathrm{O}$ bulk composition of discharged fluids, $\delta^{18} \mathrm{O}_{\text {tot }(\mathrm{f})}$, is constant, unless oxygen addition or loss occurs. Because the totality of oxygen in the magmatic gas component(s) feeding the hydrothermal system is sourced by $\mathrm{H}_{2} \mathrm{O}$ and $\mathrm{CO}_{2}$ (making up $>95 \%$ of magmatic gases at depths of interest), $\delta^{18} \mathrm{O}_{\text {tot(f) }}$ values are computed as

$$
\begin{aligned}
\delta^{18} \mathrm{O}_{\text {tot(f) }} & =\delta^{18} \mathrm{O}_{\mathrm{H}_{2} \mathrm{O}+\mathrm{CO}_{2}(\mathrm{f})}=\chi_{\mathrm{CO}_{2}} \delta^{18} \mathrm{O}_{\mathrm{CO}_{2}(\mathrm{f})}+\left(1-\chi_{\mathrm{CO}_{2}}\right) \delta^{18} \mathrm{O}_{\mathrm{H}_{2} \mathrm{O}(\mathrm{f})} \\
& =\delta^{18} \mathrm{O}_{\mathrm{H}_{2} \mathrm{O}(\mathrm{f})}+\chi_{\mathrm{CO}_{2}} 1000 \ln \alpha\left(T_{\mathrm{f}}\right)
\end{aligned}
$$

where $\chi_{\mathrm{CO}_{2}}$ is the atomic fraction of oxygen in $\mathrm{CO}_{2} ; \delta^{18} \mathrm{O}_{\mathrm{H}_{2} \mathrm{O}(\mathrm{f})}$ is the value measured in the fumarolic fluids; $\alpha\left(T_{\mathrm{f}}\right)$ is the $\mathrm{CO}_{2}-\mathrm{H}_{2} \mathrm{O}$ oxygen fractionation factor (Richet et al., 1977) at fumarolic temperatures, $T_{\mathrm{f}}$, and

$\chi_{\mathrm{CO}_{2}}=2 X_{\mathrm{CO}_{2}} /\left(1+X_{\mathrm{CO}_{2}}\right)$

where $X_{\mathrm{CO}_{2}}$ is the molar fraction of $\mathrm{CO}_{2}$ in the discharged gas.

Because the gas phase ascends as a superheated vapour, liquid water is absent for $T \geq T_{\mathrm{f}}$ (Caliro et al., 2007), $\delta^{18} \mathrm{O}_{\mathrm{H}_{2} \mathrm{O}(\mathrm{f})+\mathrm{CO}_{2}(\mathrm{f})}$ is not affected by condensation and can be considered representative of the isotopic composition at the bottom of the hydrothermal system, where magmatic gases enter.

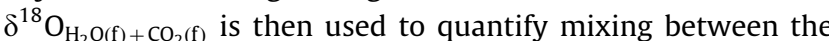
hydrothermal and magmatic components. In the $\delta^{18} \mathrm{O}_{\mathrm{H}_{2} \mathrm{O}(\mathrm{f})+\mathrm{CO}_{2}(\mathrm{f})}$ vs. $\chi_{\mathrm{CO}_{2}}$ diagram (Fig. 2) the Solfatara data array can be interpreted as resulting from the combination of various mixing patterns, each involving a "heavy" oxygen (magmatic) end-member and a $\mathrm{CO}_{2}$-poor component, characterized by a lower $\delta^{18} \mathrm{O}$ value (hydrothermal). The following isotopic balance allows estimating the fraction of magmatic fluids in the fumaroles, $Y$ :

$\delta^{18} \mathrm{O}_{\mathrm{H}_{2} \mathrm{O}(\mathrm{f})+\mathrm{CO}_{2}(\mathrm{f})}=\delta^{18} \mathrm{O}_{\mathrm{H}_{2} \mathrm{O}(\text { hyd })+\mathrm{CO}_{2}(\text { hyd })} \times(1-\mathrm{Y})+\delta^{18} \mathrm{O}_{\mathrm{H}_{2} \mathrm{O}(\mathrm{m})+\mathrm{CO}_{2}(\mathrm{~m})} \times Y$

with hyd and $m$ subscripts referring to the hydrothermal and magmatic fluids, respectively. For the magmatic component equilibrated with trachyte at $1173 \mathrm{~K}$, we have that

$\delta^{18} \mathrm{O}_{\mathrm{H}_{2} \mathrm{O}(\mathrm{m})+\mathrm{CO}_{2}(\mathrm{~m})}=\left(1-\chi_{\mathrm{CO}_{2}(\mathrm{~m})}\right) \delta^{18} \mathrm{O}_{\mathrm{H}_{2} \mathrm{O}(\mathrm{m})}+\chi_{\mathrm{CO}_{2}(\mathrm{~m})} \delta^{18} \mathrm{O}_{\mathrm{CO}_{2}(\mathrm{~m})}$

By assuming isotopic equilibrium between the magmatic fluids and local volcanic trachytes $\left(\delta^{18} \mathrm{O}_{\text {trachyte }}=8.20 \%\right.$; Turi et al., 1991), and considering isotopic fractionation between rocks, water and $\mathrm{CO}_{2}$ (Zhao and Zheng, 2003; Zheng, 1993), average values of $\delta^{18} \mathrm{O}_{\mathrm{H}_{2} \mathrm{O}(\mathrm{m})}(8.69 \%)$ and $\delta^{18} \mathrm{O}_{\mathrm{CO}_{2}(\mathrm{~m})}(11.88 \%$ o $)$ can be derived (Caliro et al., 2007). The Magmatic Line of Fig. 2

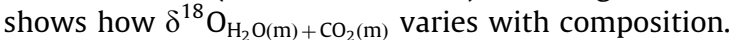

The ensemble of datapoints obtained via Eq. (1) depict a fan

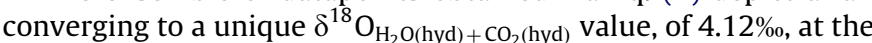
$\mathrm{CO}_{2}$ content $\left(\chi_{\mathrm{CO}_{2}}=0.2\right.$, or $\left.X_{\mathrm{CO}_{2}}=0.11\right)$ of the hydrothermal endmember (Caliro et al., 2007) (Fig. 2). In light of the very small analytical errors on oxygen isotopes (within the size of data

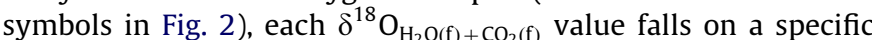
mixing line between such a constant hydrothermal end-member and a variable magmatic component along the theoretical magmatic line. $\chi_{\mathrm{CO}_{2}(\mathrm{~m})}$, hence $X_{\mathrm{CO}_{2}(\mathrm{~m})}$, can be estimated point by point at the intersection of each mixing line connecting the hydrothermal end-member with the magmatic line

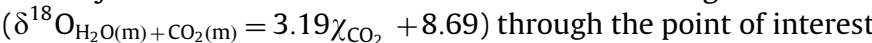
(Fig. 2). Re-working the expressions for a straight line from two points and for the intersection between two straight lines, we obtain

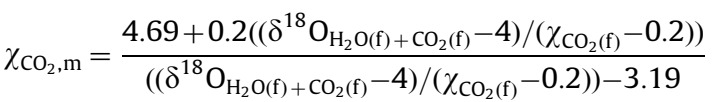

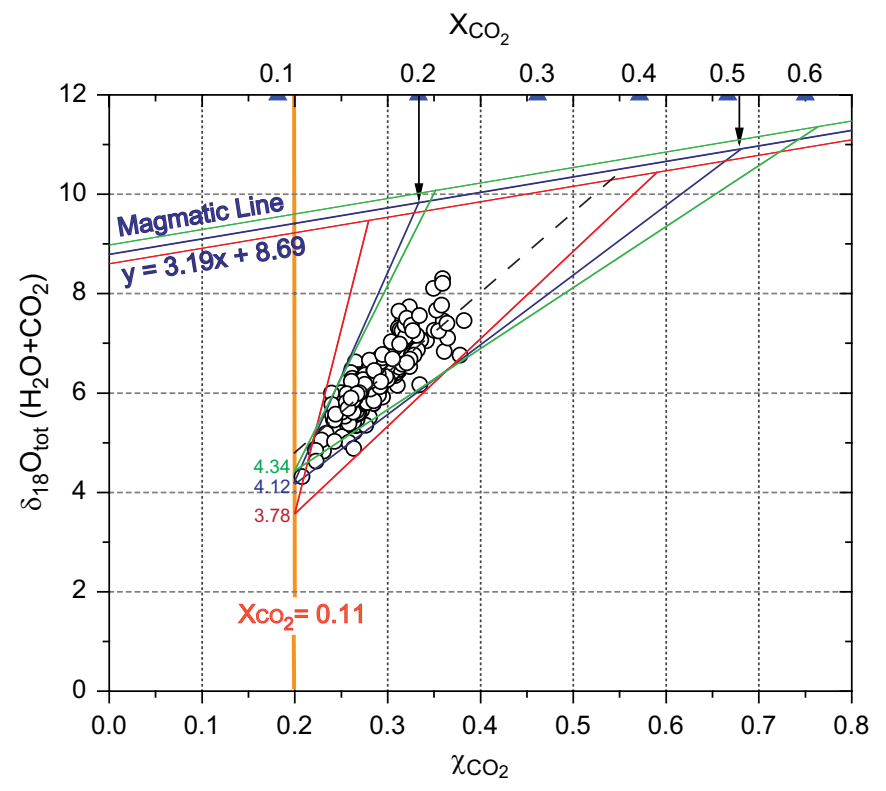

Fig. 2. Plot of the isotopic values of total (i.e., $\mathrm{H}_{2} \mathrm{O}+\mathrm{CO}_{2}$ ) oxygen vs. atom fraction of $\mathrm{CO}_{2}$ oxygen ( $\chi_{\mathrm{CO}_{2}}$ on bottom $X$-axis) and $\mathrm{CO}_{2}$ molar fraction $\left(\chi_{\mathrm{CO}_{2}}\right.$ on upper $X$-axis) in fumarolic discharges. The reference hydrothermal end-member turns out to be characterized by $X_{\mathrm{CO}_{2} \text { (hyd) }}=0.11$ and $\delta^{18} \mathrm{O}_{\mathrm{H}_{2} \mathrm{O}+\mathrm{CO}_{2} \text { (hyd) }}=4.12 \%$. Oxygen isotope composition of the magmatic end-member varies along the Magmatic Line ( $T=1173 \mathrm{~K}$ ), depending on the $\mathrm{H}_{2} \mathrm{O}-\mathrm{CO}_{2}$ composition of the magmatic gas component (Caliro et al., 2007). $\delta^{18} \mathrm{O}$ data are from the literature (Caliro et al., 2007; Chiodini et al., 2010a). The dashed line is the linear regression on all data and intersects the hydrothermal end-member composition for $\delta^{18} \mathrm{O}_{\mathrm{H}_{2} \mathrm{O}+\mathrm{CO}_{2} \text { hyd }}=4.65 \%$. Coloured line pairs originating from $X_{\mathrm{CO}_{2} \text {,hyd }}=0.11$ and $\delta^{18} \mathrm{O}$ values of 3.78 (red) and $4.34 \%$ (green) are drawn to show variations in $X_{\mathrm{CO}_{2}, \mathrm{~m}}$ at the intersection with the Magmatic Line. For this purpose, we considered errors on $\delta^{18} \mathrm{O}_{\mathrm{H}_{2} \mathrm{O}+\mathrm{CO}_{2}, \mathrm{~m}}$ values ( $\pm 0.3 \%$, Caliro et al., 2007), in order to explore maximum uncertainties on $X_{\mathrm{CO}_{2}, \mathrm{~m}}$. (For interpretation of the references to colour in this figure legend, the reader is referred to the web version of this article.)

\subsection{Magmatic degassing}

The numerical simulations of magmatic degassing were performed by means of an integrated thermodynamic technique for gas-melt saturation (Moretti et al., 2003) that includes (1) mass balances for volatile components in the liquid and gas phases, (2) equation of state for non-ideal behaviour of the gas phase in the system $\mathrm{H}_{2} \mathrm{O}-\mathrm{CO}_{2}-\mathrm{H}_{2} \mathrm{~S}-\mathrm{SO}_{2}$ (Belonoshko et al., 1992), (3) modelling of the mixed $\mathrm{H}_{2} \mathrm{O}, \mathrm{CO}_{2}$ and sulphur dissolution in melts (Baker and Moretti, 2011; Moretti and Ottonello, 2005; Papale et al., 2006), (4) modelling of the redox state of both liquid (Fe and $\mathrm{S}$ species) and gas phase (S-bearing species) (Moretti, 2005; Moretti and Papale, 2004), (5) closed-system and open-system degassing options, (6) crystallization, by subtraction of mass of solid at each computational step (e.g., Aiuppa et al., 2007), and (6) gas infiltration (fluxing), i.e., addition of gas at each computational step.

Parameters used in simulations are independent of isotopic inversion of fumarolic data and are based on melt inclusion (MI) studies and experimental petrology (Roach, 2005; Fabbrizio et al., 2009). Adopted total $\mathrm{H}_{2} \mathrm{O}$ and $\mathrm{CO}_{2}$ contents (Table 1) are from MI studies of the shallow magmatic system feeding recent trachytic eruptions at CFc (Arienzo et al., 2010). Total sulphur content is from authors' unpublished data on least evolved trachytic MIs in samples from recent ( $<5000 \mathrm{ka}$ ) eruptions (see Appendix). All computations refer to redox conditions corresponding to $1.2 \mathrm{log}$ units above the Nickel-Nickel Oxide (NNO) buffer (Table 1), in agreement with observations on CFc magmatic systems (Arienzo et al., 2010; Mangiacapra et al., 2008; Roach, 2005; Fabbrizio et al., 2009). 
Table 1

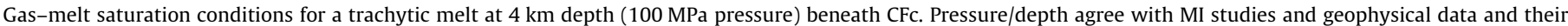
interpretations. Total volatiles, temperature and oxygen fugacity comply with MIs investigations and experimental petrology.

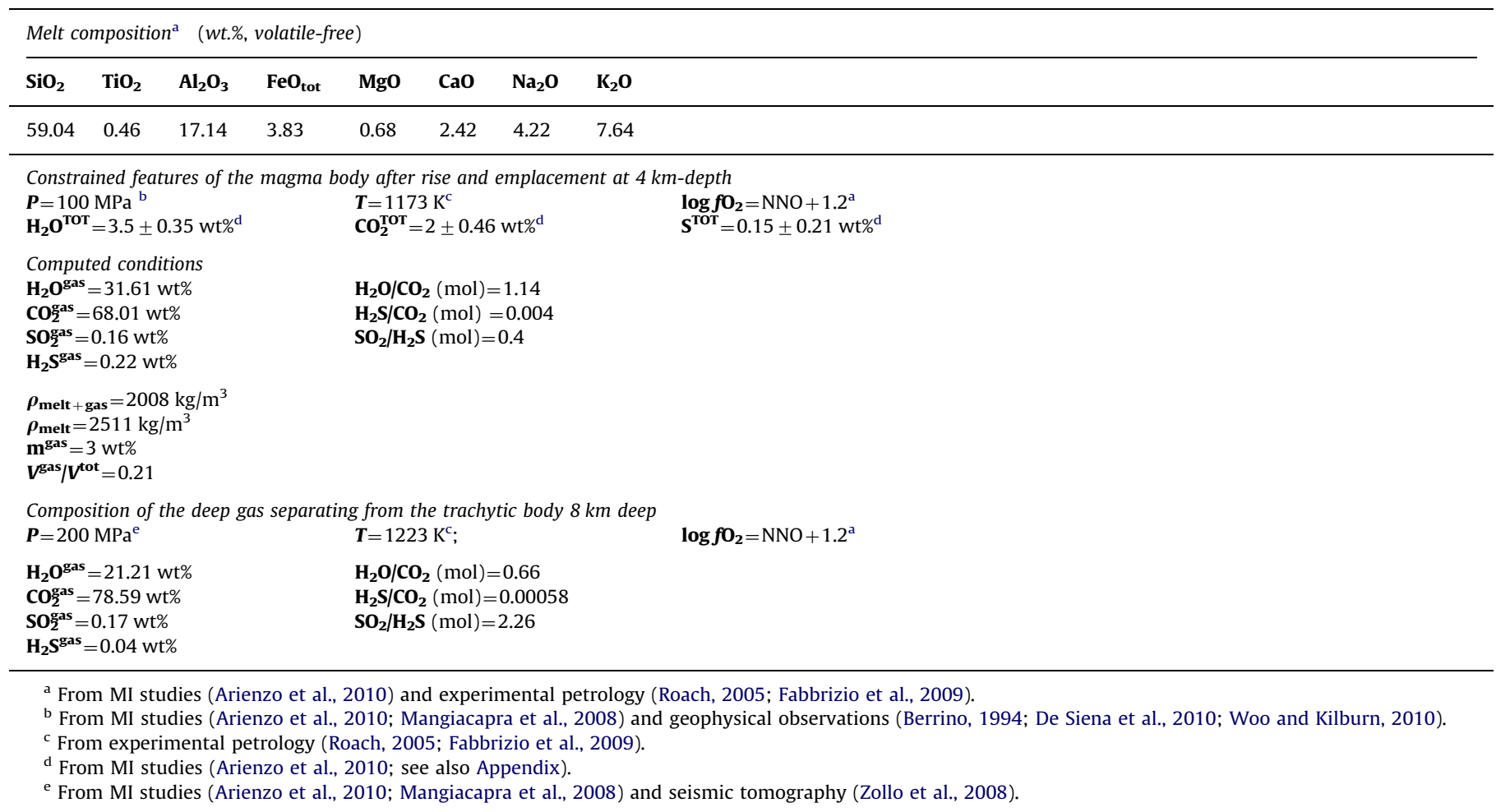

The model returns gas fractions and compositions, and magma densities before and after gas separation along degassing patterns at the specified pressure of $100 \mathrm{MPa}$ ( $4 \mathrm{~km}$ depth) and a temperature of $1173 \mathrm{~K}$ (Table 1 ). The case of gas fluxing is considered by infiltrating this shallow magma with the gas separated from a deep ( $8 \mathrm{~km}$ depth, or $200 \mathrm{MPa}$ ) reservoir of the same trachytic composition, but at a temperature of $1223 \mathrm{~K}$ (Roach, 2005).

\section{Results and discussion}

\subsection{Magmatic component in fumarolic gases}

The nature of the magmatic gas entering the hydrothermal system has remained ambiguous hitherto, because the measured trends can be reproduced by using variable magmatic compositions (in terms of gas species concentrations) interacting with hydrothermal fluids in variable proportions and under variable conditions. A hypothesis which has been put forward implies a compositionally constant magmatic gas component, and ascribes the observed variations in surface manifestations to variable proportions of mixing with hydrothermal fluids (Caliro et al., 2007; Chiodini et al., 2010a,b, 2011). We show here that this approach can only partially explain time series in terms of origin of magmatic gases, magma storage depths, with consequences for volcanic hazards assessment and short-term volcano behaviour forecast.

The isotopic inversion is carried out considering that fumarolic emissions can result from mixing between fluid end-members represented by a substantially constant hydrothermal component and one or more magmatic gas components. In fact, intersection of each mixing line with the theoretical magmatic line identifies $\mathrm{H}_{2} \mathrm{O}_{(\mathrm{m})} / \mathrm{CO}_{2(\mathrm{~m})}$ values between $1\left(X_{\mathrm{CO}_{2}(\mathrm{~m})} \approx 0.5\right)$ and $5\left(X_{\mathrm{CO}_{2}(\mathrm{~m})}\right.$ $\approx 0.2$ ). In such an interpretation, isotopic features of surface fluids (Figs. 1d and 2) would clearly be dependent on the $\mathrm{H}_{2} \mathrm{O}-$ $\mathrm{CO}_{2}$ composition of the entering magmatic gas and would show the existence of a minimum of three distinct isotopic sources involved in the generation of the fumarolic discharges and limiting the field of isotopic variation: the hydrothermal source (we use a reference value of $\delta^{18} \mathrm{O}=4.12 \%$, determined as in the Appendix) and two magmatic gas sources corresponding to a more primitive $\left(\mathrm{CO}_{2}\right.$-rich) and a more residual $\left(\mathrm{H}_{2} \mathrm{O}\right.$-rich) gas phase involved in the generation of the magmatic gas component.

Data in Fig. 2 permit a point-by-point quantification of the hydrothermal and magmatic components in fumarolic gases via Eq. (3). Fig. $3 \mathrm{~A}$ and $\mathrm{B}$ shows the retrieved magmatic gas fraction in the fumarolic output, and $\mathrm{H}_{2} \mathrm{O}_{(\mathrm{m})} / \mathrm{CO}_{2(\mathrm{~m})}$ ratio in the magmatic component. Magmatic gas fraction (Fig. 3A) and $\mathrm{H}_{2} \mathrm{O}_{(\mathrm{m})} / \mathrm{CO}_{2(\mathrm{~m})}$ ratio (Fig. 3B) are anticorrelated and show specular trends, confirming that $\mathrm{CO}_{2(\mathrm{f})}$ high concentrations are caused by an increased proportion of deep magmatic gases. However, the composition of the magmatic gas component is not constant, rather shows oscillations that are due to the variable proportions of gases exsolved by different magmatic sources. It is straightforward to conclude that the detected variations of both $\mathrm{CH}_{4(\mathrm{f})} / \mathrm{CO}_{2(\mathrm{f})}$ and $\mathrm{H}_{2} \mathrm{~S}_{(\mathrm{f})} / \mathrm{CO}_{2(\mathrm{f})}$ ratios, although controlled to a certain extent by reactions occurring in the hydrothermal system, should also reveal the compositional variability of the magmatic gases rising at shallow depths.

\subsection{Unzipping multiple magma sources}

At least two magmatic sources have been identified at CFc: (1) a deep, stable source, corresponding to the large magma reservoir identified at $8 \mathrm{~km}$ depth by seismic tomography (Zollo et al., 2008), considered part of the complex system that has fed the volcanism over the past several thousand years (Arienzo et al., 2010; Mangiacapra et al., 2008) and which developed on top of a $\mathrm{CO}_{2}$-rich magma source supplying the entire Phlegraean district (Mormone et al., 2011; Moretti et al., in press); and (2) a shallow magma batch that intruded at about $4 \mathrm{~km}$ depth during the 198284 unrest episode (Berrino, 1994; De Siena et al., 2010; Trasatti 
A

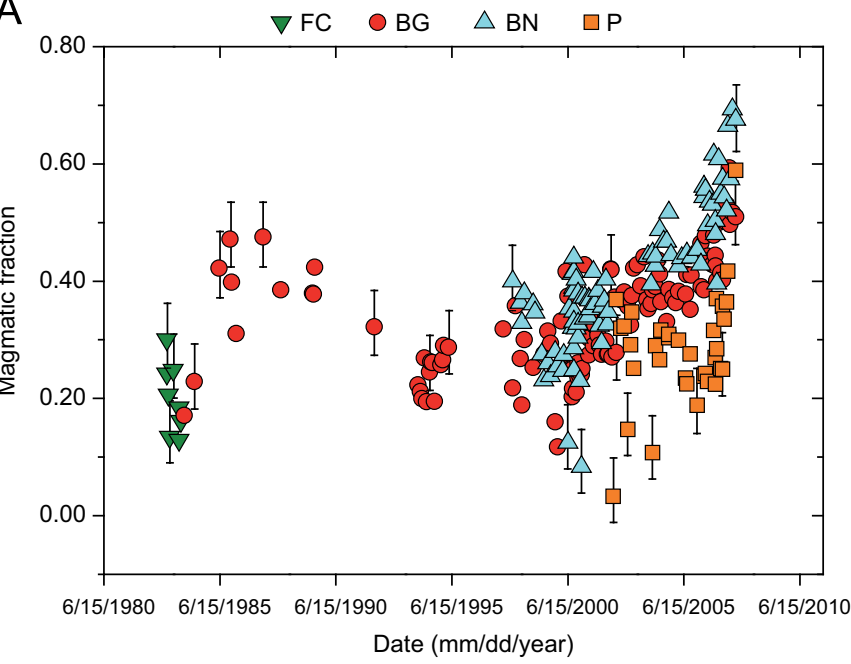

B

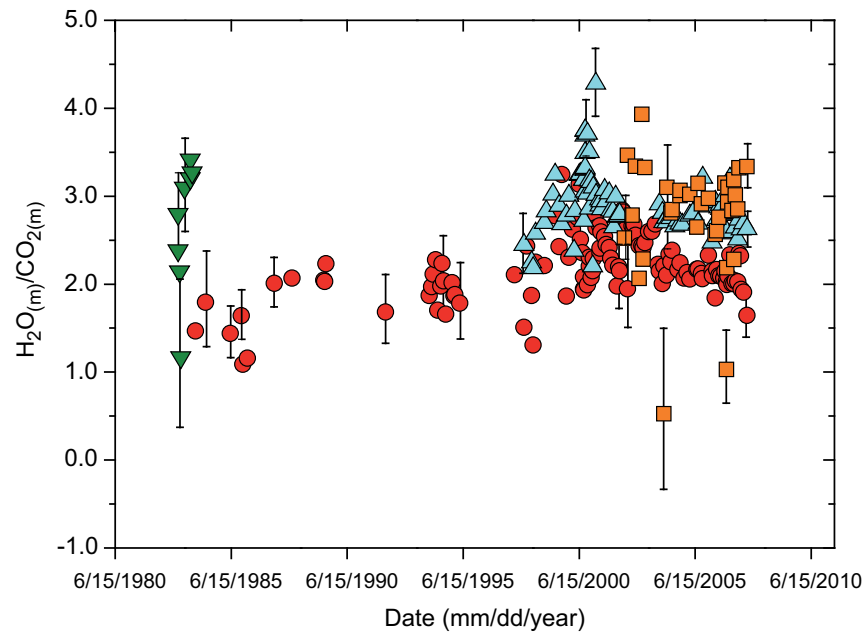

Fig. 3. Chronograms of isotope-derived quantities. Panel (A) reports the magmatic molar gas fraction $(Y)$ and panel $(B)$ the molar $\mathrm{H}_{2} \mathrm{O}_{(\mathrm{m})} / \mathrm{CO}_{2(\mathrm{~m})}$ ratio, both retrieved by means of isotopic analysis (Fig. 2) on Solfatara fumarolic discharges. Vertical bars are plotted for selected points in both panels and represent maximum

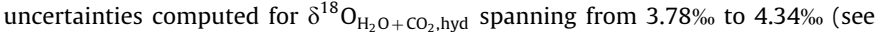
Fig. 2)

et al., 2011; Woo and Kilburn, 2010). This picture allows interpretation of the compositional variations of the magmatic component of the fumarolic gases through time (Fig. 2). Such variations are in fact consistent with mixing of gases exsolved from the two identified magmatic sources.

Independent constraints based on seismic attenuation tomography (De Siena et al., 2010) suggest that this small sill-like intrusion was already partly solid at the time of the 1982-84 unrest crisis. Furthermore, residual ground deformation (Woo and Kilburn, 2010) and sulphur isotope $\left(\delta^{34} \mathrm{~S}_{\mathrm{H}_{2} \mathrm{S(f)}}\right)$ values (around $0 \%$ vs. Canyon Diablo Troilite, CDT in 1982-1987 and averaging at $+1.7 \%$ in $1998-2001$; Allard et al., 1991; Marini et al., 2011) require that this magma intrusion was largely crystallized about $20 \mathrm{yr}$ after emplacement. The crystallizing shallow magma batch must have been one of the sources of volatiles injected into the geothermal system. Total volatile contents have been constrained for past CFc eruptions, such as the 4.1 ka B.P. Agnano-Monte Spina eruption for which a similar mechanism of pre-eruptive, small-size shallow intrusion has been is hypothesized (Arienzo et al., 2010). If completely exsolved by a crystallizing magma body similar in size to that intruded during the 1982-84 unrest episode (Berrino, 1994; Trasatti et al., 2011), such total volatile contents would account for about one-third of the $1500 \mathrm{t} /$ day of $\mathrm{CO}_{2}$ estimated as an average flux at Solfatara over the past $25 \mathrm{yr}$ (Chiodini et al., 2010b) Therefore, degassing from the shallow, crystallizing magma body has significantly contributed to the fumarolic outputs for a long time after emplacement in 1982-84.

Numerical simulations (see section 3.2, Table 1 and Appendix) of the thermodynamic relationships between a typical Phlegraean trachyte and a volatile phase with composition in the $\mathrm{C}-\mathrm{O}-\mathrm{S}-\mathrm{H}$ system (Moretti et al., 2003) show that progressive crystallization of the shallow magma body results in a gas phase progressively enriched in $\mathrm{H}_{2} \mathrm{O}$ and $\mathrm{H}_{2} \mathrm{~S}$ with respect to $\mathrm{CO}_{2}$; only about $40 \%$ of crystallization would practically exhaust the $\mathrm{CO}_{2}$ flux (Fig. 4). However, the $\mathrm{CO}_{2}$ flux shows no signs of waning (Caliro et al., 2007; Chiodini et al., 2011, 2010a) (cf. Fig. 1). Additionally, a single crystallizing gas source would produce a volatile phase progressively depleted in ${ }^{13} \mathrm{C}$ (e.g., Holloway and Blank, 1994), whereas the $\delta^{13} \mathrm{C}$ values measured at Solfatara fumaroles do not highlight such a trend, with values fluctuating around a substantially constant average (Allard et al., 1991; Caliro et al., 2007).

The above facts suggest that although the shallow magma batch must have been effective in feeding the overlying geothermal system and ultimately the fumarolic discharges, its degassing alone cannot explain the characteristics of the Solfatara gas output. Those characteristics, and particularly the substantial variations in composition of the magmatic gas fraction displayed in Fig. 3, are instead consistent with superposition of shallow and deep degassing sources contemporaneously effective at least for $20 \mathrm{yr}$ after the shallow magma emplacement, until exhaustion of its original volatile content.

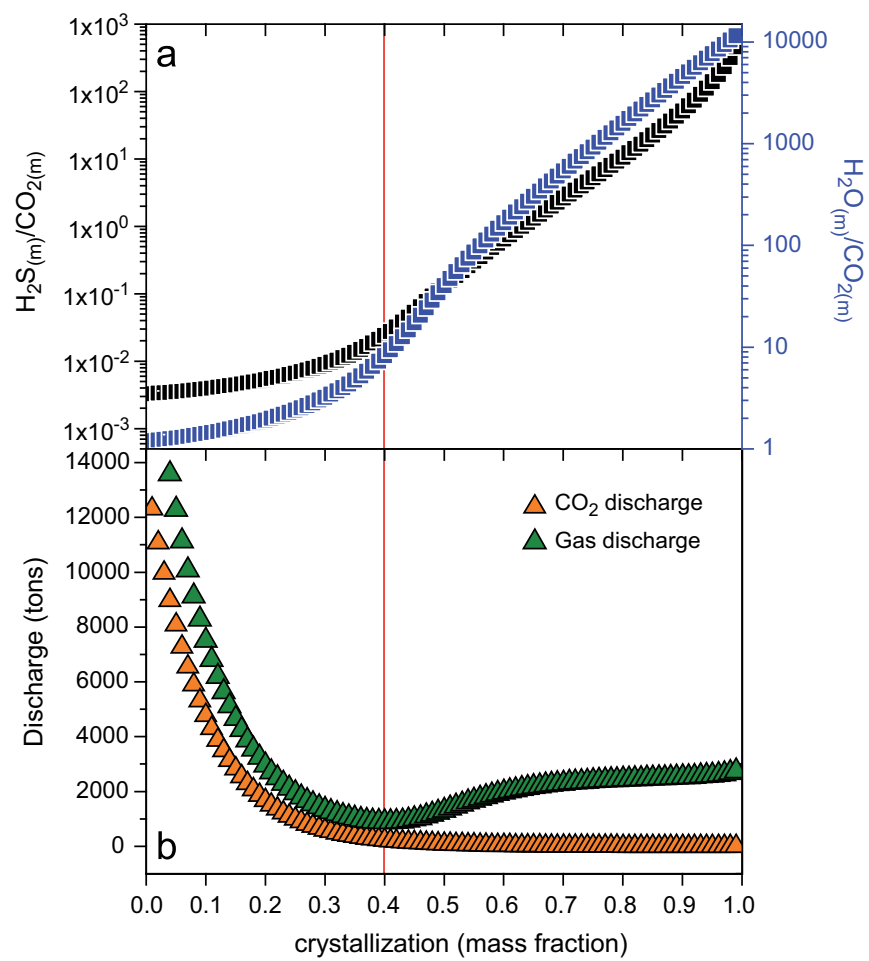

Fig. 4. Model computations of the degassing of a magma body emplaced at $4 \mathrm{~km}$ depth as a function of crystallization. An initial mass of the magma body of $\sim 2 \times 10^{11} \mathrm{~kg}$ was used (Berrino, 1994). Panel (a): variation of gaseous magmatic (molar) $\mathrm{H}_{2} \mathrm{O} / \mathrm{CO}_{2}$ and $\mathrm{H}_{2} \mathrm{~S} / \mathrm{CO}_{2}$ ratios with crystallization. Panel (b): variation of discharged gas amounts with crystallization. The gas discharge would decay progressively after shallow magma emplacement (i.e., since 1982-84) and gas exhaustion would be reached after $40 \mathrm{wt} \%$ of magma crystallization. Note the increase of discharged $\mathrm{H}_{2} \mathrm{O}$ after $40 \mathrm{wt} \%$ crystallization (Panel c), due to the residual stripping of the more soluble water component after $\mathrm{CO}_{2}$ exhaustion. 
$\mathrm{C}-\mathrm{O}-\mathrm{S}-\mathrm{H}$-trachyte equilibrium thermodynamics at $100 \mathrm{MPa}$ ( $4 \mathrm{~km}$ depth) and $1123 \mathrm{~K}$ is made by allowing the shallow trachytic magma to crystallize and degas while being periodically infiltrated by a $\mathrm{CO}_{2}$-rich gas of deeper provenance (see Table 1 ). Volatile components are partitioned between melt and gas only. In particular, FeS precipitation was not considered, because sulphur contents are much less than the sulphur content at sulphide saturation, or SCSS, consistent with the relatively high $\mathrm{fO}_{2}$ (Moretti and Baker, 2008; Baker and Moretti, 2011). Calculation of gas-melt saturation properties show that the retrieved compositional trends of the magmatic gas component in the

A

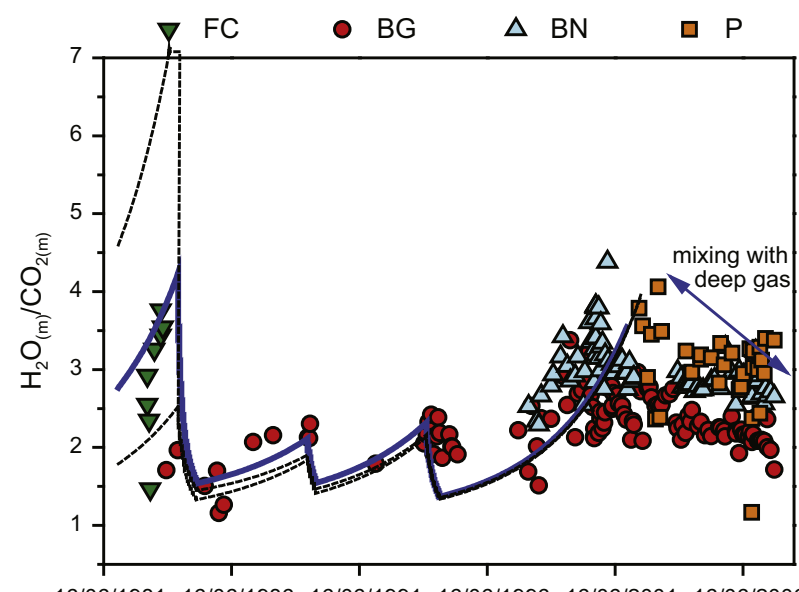

16/06/1981 16/06/1986 16/06/1991 16/06/1996 16/06/2001 16/06/2006

Date $(\mathrm{mm} / \mathrm{dd} /$ year $)$

B

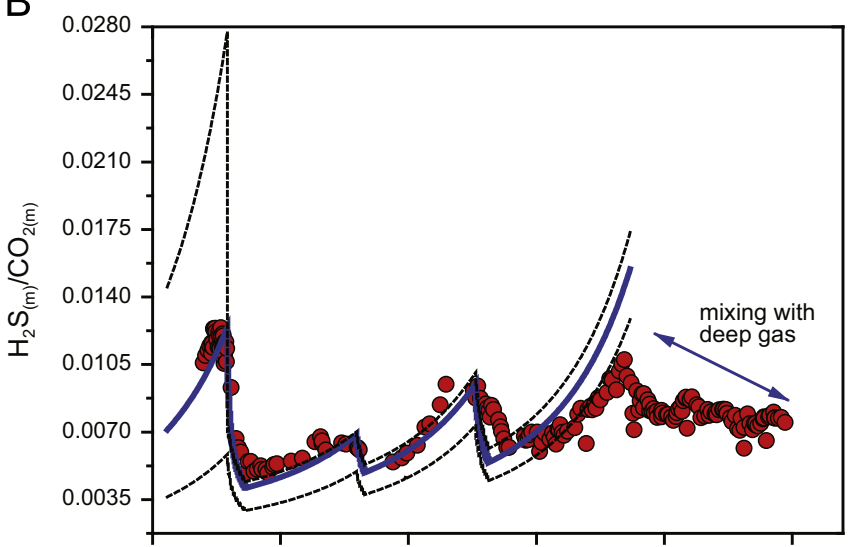

16/06/1981 16/06/1986 16/06/1991 16/06/1996 16/06/2001 16/06/2006 Date $(\mathrm{mm} / \mathrm{dd} /$ year $)$

C

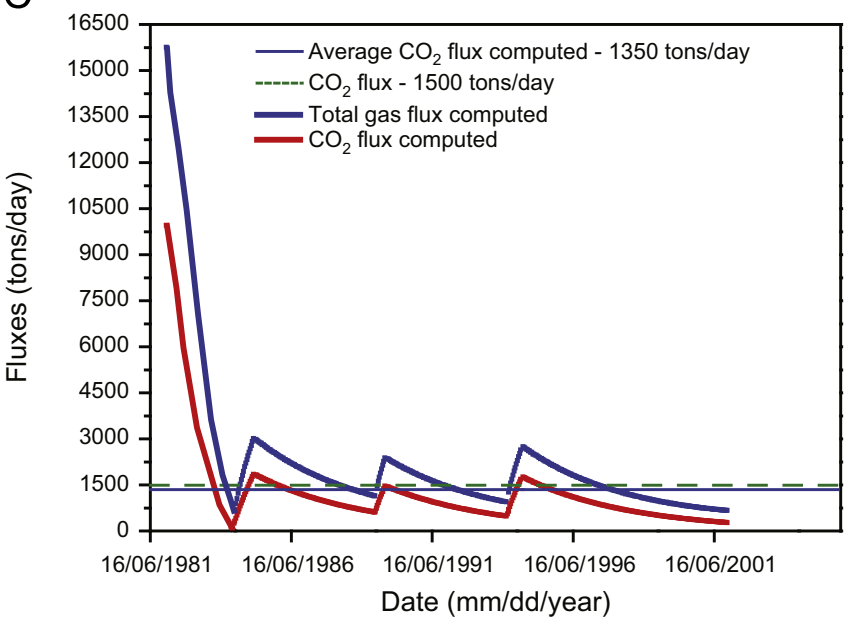

fumaroles can be reproduced (Fig. 5). Despite uncertainties in deep gas composition that could be easily accommodated by adjusting the proportion of deep vs. shallow gas components, we prefer to keep the model running under fixed mass amounts of released and injected gas at any computational step (see Appendix for details). This choice sacrifices a perfect fit to data, but still allows constraints to be put on the crystallization process affecting the shallow magma body, showing the model performances under imposed constraints on deep gas composition, degassing and fluxing rates. Note that a significant improvement to the fitting quality of compositional data in Fig. 5 would have been also possible by introducing a solidification rate slightly variable in time. Again, we wanted to reduce as much as possible the degrees of freedom, and used a constant crystallization value of $1 \%$ of the total magma every 143 days. Constant crystallization rate for close-to-eutectic trachyte is a reasonable approximation of the Avrami equation (Lasaga, 1998), resulting in about $75-80 \%$ solidification of the shallow magmatic intrusion in year 2000, perfectly consistent with independent geophysical estimates (De Siena et al., 2010; Woo and Kilburn, 2010) and with the increase of $\delta^{34} \mathrm{~S}_{\mathrm{H}_{2} \mathrm{~S}(\mathrm{f})}$ (Marini et al., 2011). The implication is that the contribution from the solidifying shallow source to the magmatic component in fumaroles must have been waning progressively until it becomes negligible, leaving the sole deep source during the last few years. Such behaviour is reflected in the different compositional trend acquired after year 2000 by fumarolic gases that do not show the oscillations of the preceding $20 \mathrm{yr}$ : they have progressively and continuously evolved until year 2010, when they reached a substantially stable $\mathrm{H}_{2} \mathrm{O}_{(\mathrm{f})} / \mathrm{CO}_{2(\mathrm{f})}$ ratio (Fig. 1). Although lack of published isotopic data prevents computation of the magmatic component after year 2010, similiarities in the general trends of fumarolic (Fig. 1) and magmatic (Fig. 3) $\mathrm{H}_{2} \mathrm{O} / \mathrm{CO}_{2}$ ratios suggests that the present-day mole fraction of magmatic volatiles in the fumaroles is in the range 0.7-0.8, and that the $\mathrm{H}_{2} \mathrm{O}_{(\mathrm{m})} / \mathrm{CO}_{2(\mathrm{~m})}$ ratio in the magmatic gas phase entering the hydrothermal system is decreasing to a value below 2 .

We also computed the amount of gas discharged, in order to verify whether our results are compatible or not with measured soil $\mathrm{CO}_{2}$ fluxes (1500 t/day; Chiodini et al., 2010a). Computation of fluxes holds under a lumped approximation at the depth of melt/ gas equilibria, thus without accounting for transport issues governing gas propagation through a porous medium after separation from the magma. Our simulation returns a variable $\mathrm{CO}_{2}$ flux, with peaks at around $2000 \mathrm{t} /$ day after the 1982-84 unrest. Therefore, one should not expect to measure the same variations at surface, where mean discharge rates show smoothed fluctuations and the degassing phenomenon may survive long after deep feeding has ceased (Todesco et al., 2010). However, our 18-yr average $\mathrm{CO}_{2}$ flux

Fig. 5. Chronograms comparing estimated/measured vs. computed gas ratios and fluxes. Panel (A): isotope-derived (datapoints) and model-computed (heavy blue and thin black lines) molar $\mathrm{H}_{2} \mathrm{O}_{(\mathrm{m})} / \mathrm{CO}_{2(\mathrm{~m})}$. Panel (B): measured molar $\mathrm{H}_{2} \mathrm{~S}_{(\mathrm{f})} / \mathrm{CO}_{2(\mathrm{f})}$ ratios (datapoints) and model-computed molar $\mathrm{H}_{2} \mathrm{~S}_{(\mathrm{m})} / \mathrm{CO}_{2(\mathrm{~m})}$ ones (heavy blue and thin black lines). Only BG datapoints have been reported. In both panels, the heavy blue line is the solution for initial $\mathrm{H}_{2} \mathrm{O}^{\mathrm{TOT}}, \mathrm{CO}_{2}^{\mathrm{TOT}}$ and $\mathrm{S}^{\mathrm{TOT}}$ values of $3.5,2$ and $0.15 \mathrm{wt} \%$, respectively, whereas thin black lines represent model results accounting for uncertainties on total volatiles. With reference to the first peak (year 1984), in both panels the uppermost line is computed for $\mathrm{H}_{2} \mathrm{O}^{\mathrm{TOT}}, \mathrm{CO}_{2}^{\mathrm{TOT}}$ and $\mathrm{S}^{\mathrm{TOT}}$ values of $3.85 \%, 1.54 \%$ and $0.176 \%$, respectively, whereas the lowermost one for $3.15,2.46$ and $0.125 \mathrm{wt} \%$. Panel (c): solid lines: model-computed total gas and $\mathrm{CO}_{2}$ fluxes from the shallow magma intrusion (scaled on $2 \times 10^{11} \mathrm{~kg}$ of initial magma); dashed lines: average $\mathrm{CO}_{2}$ flux measured at the Solfatara crater (1500 t/day; Chiodini et al., 2010a), here extended over the 1982-2000 time window (6600 days), and modelcomputed $\mathrm{CO}_{2}$ flux (1350 t/day, equal to the computed bulk $\mathrm{CO}_{2}$ discharge divided by 6600 days). Peaks of gas ratios in the year 2000 (panels $A$ and B), and the associated waning of gas discharge rates (panel C), mark a transition due to exhaustion of shallow magma degassing, and its replacement by the deep-reservoir gas (not shown). (For interpretation of the references to colour in this figure legend the reader is referred to the web version of this article.) 
(from 1982 to 2000) yields 1350 t/day, (Fig. 5c), which is in good agreement with measured soil fluxes at surface. This is highly reasonable, because average fluxes, after a long time, should have similar values as those measured at surface independently of how gas propagation from depth occurs. Moreover, we take this consistency as a good indication that the whole degassing process can be sustained by more than one shallow magma body.

\subsection{On model accuracy and alternative approaches}

The accuracy of our model depends on parameters and assump-

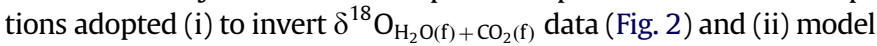
the magmatic system (size, $\mathrm{P}, \mathrm{T}, \mathrm{fO}_{2}$, composition, total volatiles). The major source of uncertainties is related to the choice of

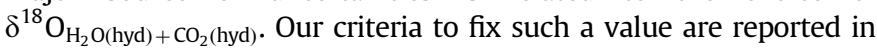
the Appendix. Here, it is worth noting that we avoided extrapolation of simple linear regressions to the hydrothermal end-member composition. The bulk regression line (dashed in Fig. 2) crosses the $\chi_{\mathrm{CO}_{2}}=0.2$ axis at a $\delta^{18} \mathrm{O}_{\mathrm{H}_{2} \mathrm{O}+\mathrm{CO}_{2}}$ value of $4.65 \%$. This value is significantly higher than $\delta^{18} \mathrm{O}_{\mathrm{H}_{2} \mathrm{O}+\mathrm{CO}_{2}}$ of datapoints falling close to such an axis, particularly the one at $\chi_{\mathrm{CO}_{2}}=0.2008\left(\mathrm{X}_{\mathrm{CO}_{2}}=0.11\right)$ and

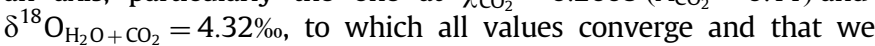
consider chemically and isotopically highly representative of the hydrothermal component. Simple regression lines cannot in fact provide good and reliable values at regression extremes, in light of the so-called central limit theorem. On the other hand, our procedure (see Appendix) allows estimating maximum dispersions in $\mathrm{H}_{2} \mathrm{O}_{(\mathrm{m})} /$ $\mathrm{CO}_{2(\mathrm{~m})}$ and magmatic gas fraction $(Y)$ (error bars in Fig. 3a,b, respectively) by constraining between $3.78 \%$ and $4.34 \%$ o the values

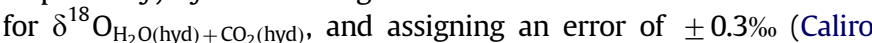

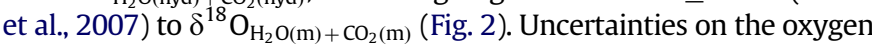
isotopic composition of the hydrothermal and magmatic components are coupled in order to maximize the range of variation for $\mathrm{H}_{2} \mathrm{O}_{(\mathrm{m})} /$ $\mathrm{CO}_{2(\mathrm{~m})}$ and $Y$. This is shown by line pairs of different colours in Fig. 2, which bracket ranges of magmatic gas composition returned by

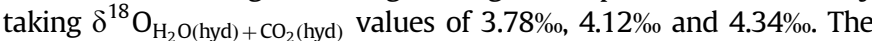
magmatic gas component shifts to higher $X_{\mathrm{CO}_{2}(m)}$ with increasing

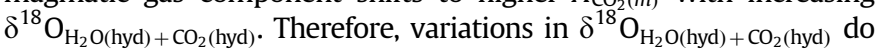
not affect appreciably the time evolution of values plotted in Fig. $3 \mathrm{~A}$ and $\mathrm{B}$ - and thus our conclusions - because all datapoints would shift in the same direction, unless $\delta^{18} \mathrm{O}_{\mathrm{H}_{2}} \mathrm{O}$ (hyd) $+\mathrm{CO}_{2}$ (hyd) varies in time.

Other major points of discussion involve the physical processes used to describe variations in $\mathrm{H}_{2} \mathrm{O}$ and $\mathrm{CO}_{2}$ and, to some extent, $\mathrm{S}$, at the fumaroles. In our model, these are governed by the different time evolution of the magma sources. Alternative models, based on the simulation of homogeneous geothermal reservoirs, show that $\mathrm{H}_{2} \mathrm{O}$ and $\mathrm{CO}_{2}$ variations are related to the variable condensation of the rising plume, depending on basal gas injection rate and duration, gas enthalpy, as well as rock properties of the reservoir and its heterogeneity (Todesco et al., 2010). If condensation is not steady and varies in time, datapoints in Fig. 2 record a shift to higher $\mathrm{CO}_{2}$ fraction and a concomitant decrease of $\delta^{18} \mathrm{O}_{\text {tot }}$ (due to oxygen loss to a liquid phase) with respect to uncondensed datapoints. One could thus infer that condensation is larger (up to $40 \mathrm{~mol} \%$, considering vapour-liquid open-system fractionation; Hoefs, 2004) the greater the pressure increase following injections of $\mathrm{CO}_{2}$-rich magmatic fluids at the bottom of the hydrothermal system (e.g., Todesco et al., 2010; Chiodini et al., 2010b). This process applies well to the entire Solfatara hydrothermal system considered as a homogeneous system, but studied fumaroles are the manifestation at surface of vapours extracted from deep reservoirs along localized ascent paths characterized by much higher permeability with respect to the surrounding medium. This generates a high permeability contrast which dramatically changes fluid transport properties, affects the rock-fluid coupling and controls the thermodynamic ascent path and consequently heat exchange between fluids and the surrounding rocks. In fact, the condensation seen in a porous rocky medium with a uniform permeability of $10^{-14} \mathrm{~m}^{2}$ (e.g., Todesco et al., 2010) is not seen along structures showing higher permeability $\left(10^{-13} \mathrm{~m}^{2}\right.$, Todesco et al., 2010). Moreover, Peluso and Arienzo (2007) have shown that $10^{-14} \mathrm{~m}^{2}$ can be a conservative permeability value for Campi Flegrei rocks. Thus, values from $10^{-13}$ to $10^{-12} \mathrm{~m}^{2}$ would be more appropriate. Such a high permeability favours the quasi-isenthalpic ascent of the $\mathrm{H}_{2} \mathrm{O}-\mathrm{CO}_{2}$ vapour, preventing condensation in a way conceptually similar to the expansion of gases by throttling in refrigeration processes.

Furthermore, and independently of rock-fluid coupling, the thermodynamics of gas expansion along the fumarolic conduit is highly controlled by the enthalpy (hence temperature) of the fluid produced after mixing of magmatic gases with the hydrothermal end-member. Therefore, the choice of initial $P-T$ conditions is highly strategic in any simulation. For this purpose, we used the VLEFlash software package ((http://www.flowphase.com/products/vleflash.html) Heidemann and Khalil, 1980; Michelsen and Heidemann, 1981; Maddox and Lilly, 1990), in order to evaluate the saturation properties of $\mathrm{H}_{2} \mathrm{O}-\mathrm{CO}_{2}$ fluids. Computations show that, with respect to pure steam, the critical point of $\mathrm{H}_{2} \mathrm{O}-\mathrm{CO}_{2}$ mixtures shifts to lower temperatures and higher pressures with increasing $\mathrm{CO}_{2}$ proportion in the fluid system: for example, critical temperature and pressure are $\sim 355^{\circ} \mathrm{C}$ and $\sim 285$ bar for $\mathrm{H}_{2} \mathrm{O}: \mathrm{CO}_{2}=89: 11$ (the composition of the hydrothermal component) and $\sim 340{ }^{\circ} \mathrm{C}$ and $\sim 315$ bar for $\mathrm{H}_{2} \mathrm{O}: \mathrm{CO}_{2}=85: 15$ respectively. Isenthalpic decompression of a $\mathrm{H}_{2} \mathrm{O}: \mathrm{CO}_{2}=85: 15$ gas shows that condensation does not occur if this is injected at conditions inferred by Caliro et al. (2007), i.e., $360^{\circ} \mathrm{C}$ and 200 bar. Because the deep reservoir may be at temperatures up to $436{ }^{\circ} \mathrm{C}$, based on the ${ }^{13} \mathrm{C}$ exchange between $\mathrm{CO}_{2}$ and $\mathrm{CH}_{4}$ (Caliro et al., 2007), condensation throughout the fumarolic channels appears to be a subordinate process and corroborates the results of Caliro et al. (2007) about the re-equilibrations of geochemical indicators in a super-heated vapour regime. It is worth noting that lower injection temperatures $\left(350^{\circ} \mathrm{C}\right)$ are used in geothermal simulations (Chiodini et al., 2010a,b; Todesco and Berrino, 2005; Todesco et al., 2010), making condensation easier to occur.

As long as we assume a unique $\delta^{18} \mathrm{O}_{\text {tot }}$ value for the hydro-

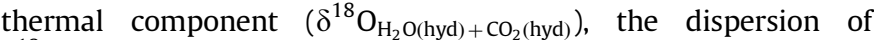

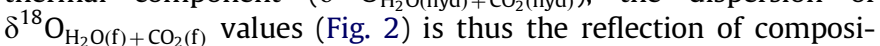
tional changes of the gas exsolved from the magma sources, rather than the effect of variable condensation. Here, it is worth stressing again on the representativeness and robustness of the datapoint at $\chi_{\mathrm{CO}_{2}}=0.2008$ and $\delta^{18} \mathrm{O}_{\text {tot }}=4.32 \%$ : even by assuming that it is affected by condensation at $105{ }^{\circ} \mathrm{C}$ (the outlet $\mathrm{T}$ for such a datapoint), this would impact less than $2 \mathrm{~mol} \%$, producing an isotopic shift less than $1 \%$ o (by using $1000 \ln \alpha_{1-v} \approx 5 \%$; Hoefs, 2004), that is within the analytical error.

The significance of $\mathrm{H}_{2} \mathrm{~S}_{(\mathrm{f})} / \mathrm{CO}_{2(\mathrm{f})}$ fluctuations, $\mathrm{H}_{2} \mathrm{~S}_{(\mathrm{f})}$ not being a conservative component, can be understood by looking at the pyrite chemical buffer:

$\mathrm{H}_{2} \mathrm{~S}+\mathrm{FeO}_{\text {p.r. }} \Leftrightarrow \mathrm{FeS}_{2, \text { py }}+\mathrm{H}_{2} \mathrm{O}+\mathrm{H}_{2}$

where subscripts p.r. and py stand for pyroclastic rock and pyrite, respectively. We can write the equilibrium constant by considering fugacities of gaseous species equal to their partial pressures, and by taking the activity of $\mathrm{FeS}_{2}$ at 1 (pure component in a pure phase), whereas that of the $\mathrm{FeO}$ component in the pyroclastic rock can be set at some constant value:

$\log K_{6}^{1, T}=\log \left[\frac{P \cdot X_{\mathrm{H}_{2} \mathrm{O}} \cdot P \cdot X_{\mathrm{H}_{2}}}{P^{2} \cdot X_{\mathrm{H}_{2} \mathrm{~S}}^{2}}\right]=\log \left[\frac{X_{\mathrm{H}_{2} \mathrm{O}} \cdot X_{\mathrm{H}_{2}}}{X_{\mathrm{H}_{2} \mathrm{~S}}^{2}}\right]=a+b / T$

The above equation depends on temperature only ( $a$ and $b$ are constant values) and must lead to a constant characteristic value 


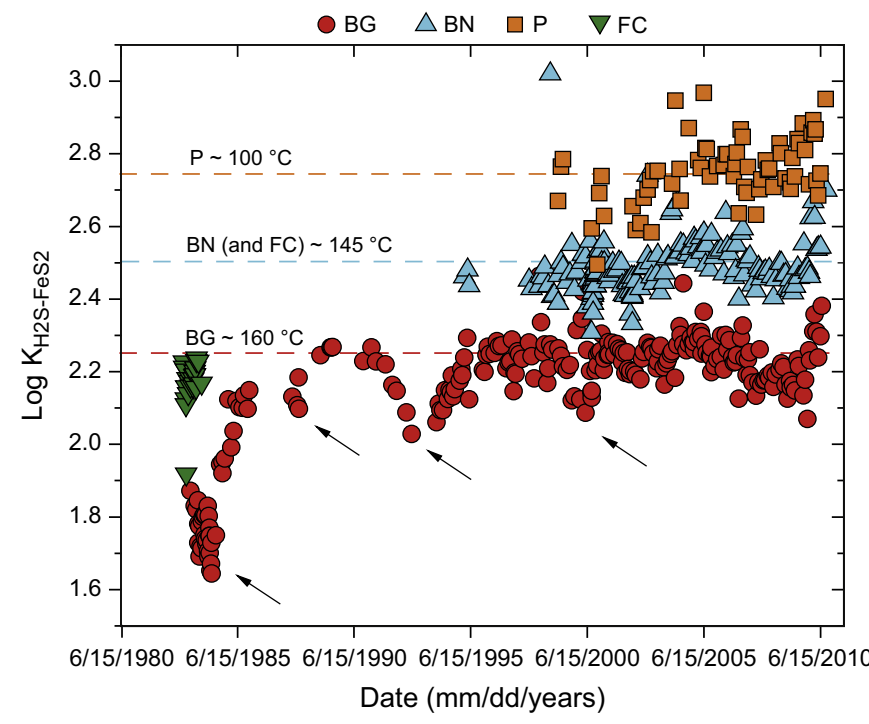

Fig. 6. Chronogram of the equilibrium constant of reaction 6 along the hydrothermal pyrite buffer for the fumaroles of interest in this study. The arrows indicate events of perturbation of the hydrothermal pyrite buffer, due to the entrance of S-rich magmatic gases generated by the advancement of crystallization in the shallow magma body. Such perturbations occur in correspondence with peaks of chemical gas ratios reported in Fig. 1. On the other hand, no chemical perturbations are observed in correspondence of $\mathrm{CH}_{4(\mathrm{f})} / \mathrm{CO}_{2(\mathrm{f})}$ minima, that is, when $\mathrm{CO}_{2}$-rich gases from the $8-\mathrm{km}$ deep magma infiltrate the shallow magma batch.

for each fumarolic system. Fig. 6 shows that this chemical equilibrium displays perturbations that have the same shape as other geochemical indicators (Fig. 1). These perturbations, leading to values lower than $\log K_{6}$ for that temperature, imply partial $\mathrm{FeS}_{2}$ dissolution, They correspond to peaks in $\mathrm{CH}_{4(\mathrm{f})} / \mathrm{CO}_{2(\mathrm{f})}$ and $\mathrm{H}_{2} \mathrm{O}_{(\mathrm{f})} / \mathrm{CO}_{2(\mathrm{f})}$ (Fig. 1), thus cannot be ascribed to an increase in oxidation or $\mathrm{H}_{2} \mathrm{O}$-loss due to condensation. When injection of hot oxidized gases occur, and $\mathrm{CH}_{4(\mathrm{f})} /$ $\mathrm{CO}_{2(\mathrm{f})}$ values reach their minima, the pyrite buffer is not perturbed (Fig. 6), because of the fast re-equilibration of the $\mathrm{H}_{2(\mathrm{f})} / \mathrm{H}_{2} \mathrm{O}_{(\mathrm{f})}$ ratio. Rather, pyrite buffer perturbations record an input of extra sulphur, in line with our model of S-release related to the advancement of magma crystallization. The strongest perturbation occurs in 1982-84, when the most important release of magmatic sulphur occurs after the magma emplacement triggering the 1982-84 unrest (Fig. 5b). A similar conclusion was reached by Chiodini et al. (1996), who reported that no liquid-vapour changes could explain the anomalous $S$ input in 1982-84. Therefore, we can reasonably argue that variations in the $\mathrm{H}_{2} \mathrm{~S}_{(\mathrm{f})} / \mathrm{CO}_{2(\mathrm{f})}$ ratio are related to sulphur degassing from the crystallizing magmatic body at $4 \mathrm{~km}$ depth. The fact that the computed magmatic degassing matches the $\mathrm{H}_{2} \mathrm{~S}_{(\mathrm{f})} / \mathrm{CO}_{2(\mathrm{f})}$ ratios of $\mathrm{BG}$ (Fig. 5b) may suggest that the $\mathrm{H}_{2} \mathrm{~S}_{(\mathrm{m})}$ input equals the $\mathrm{H}_{2} \mathrm{~S}_{(\mathrm{f})}$ output along the pyrite buffer.

Finally, the sensitivity of the degassing model was tested by changing the total volatile contents of the shallow magma (Table 1) on the basis of (i) the Papale et al. (2006) model errors on dissolved volatiles, i.e., $23 \%$ for $\mathrm{CO}_{2}, 10 \%$ for $\mathrm{H}_{2} \mathrm{O}$, and (ii) the analytical error (17\%) for sulphur (see Appendix). These errors have been combined in order to maximize uncertainties in gas ratios. Fig. 5a,b shows that uncertainties in total volatiles contents decrease right after the first episode of infiltration by the gas released from the $8 \mathrm{~km}$-deep magma, and tend to be smaller for $\mathrm{H}_{2} \mathrm{O}_{\text {(f) }} / \mathrm{CO}_{2(\mathrm{f})}$ than $\mathrm{H}_{2} \mathrm{~S}_{(\mathrm{f})} / \mathrm{CO}_{2(\mathrm{f})}$. This suggests that the multiplicity of solutions that can be obtained by changing compositional parameters cannot yield variations in gas ratios comparable to those produced by changing $\delta^{18} \mathrm{O}_{\mathrm{H}_{2}} \mathrm{O}$ (hyd) $+\mathrm{CO}_{2}$ (hyd) .

\section{Conclusions}

Distinct contributions to magmatic gases from different portions of vertically-extended plumbing systems are described at open-conduit and dome-forming volcanoes (Aiuppa et al., 2010, 2007; Edmonds et al., 2012; Shinohara, 2008; Oppenheimer et al., 2011). At closed-conduit volcanoes, characterized by the presence of hydrothermal systems, variable patterns in $\mathrm{H}_{2} \mathrm{O}_{(\mathrm{f})}, \mathrm{CO}_{2(\mathrm{f})}$ and $\mathrm{H}_{2} \mathrm{~S}_{\text {(f) }}$ have been usefully described by various degrees of steam condensation and hydrothermal buffering with pyrite. However, this approach is unsatisfactory for those cases in which condensation is not a primary control on fumarole chemistry and its oxygen isotopic composition. This study shows the role played by the magma source and its physico-chemical state must be approached to constrain variations in chemistry and discharge rates that are anchored to the changing composition of the gas phase exsolving at depth. Despite the fact that there must be multiple solutions for such a magma control (depending on total volatile contents, pressure, redox state and rate of crystallization), we show that a magma batch solidifying and degassing at shallow depth is not enough to explain all the data. This work demonstrates in fact that CFc fumarolic discharges are sourced by compositionally distinct magmatic gas reservoirs. This situation may eventually be common to a number of closed-conduit explosive volcanoes, where relatively small magma batches often ascend from large deep reservoirs without reaching the surface (e.g., Newhall and Dzurisin, 1988).

These contributions reflect degassing from magmatic sources that differ in depth, size, composition, and cooling/crystallization history. While such small, shallow magma batches, which are embedded in relatively cold rocks progressively solidify, their contribution to degassing declines until they disappear. The deep source(s) then becomes dominant or unique, restoring magmatic gas compositions similar to those likely existing before the intrusion. However, the deep and volatile-rich magma reservoir, in light of its complex convection dynamics (Longo et al., 2006), may release variable amounts of hot gases through time. The fate of shallow magma batches, which rapidly evolve around nearsolidus conditions, is likely to be highly controlled by such a variable ingression of deep hot gases and may include rejuvenation phases (Bachmann and Bergantz, 2006).

The CFC may typify conditions that are common at many closed-conduit explosive volcanoes characterized by chemically evolved viscous magmas and well-developed hydrothermal circulation. What makes CFC unique, instead, is the availability of decades-long time series of high-quality chemical and isotopic data on fumarolic gases and geophysical parameters, as well as a deep knowledge on volcanic structure, eruptive and deformation history, and magmatic feeding system. Such an extensive knowledge permits inspection and understanding at levels hardly achievable at most other explosive volcanoes, thus offering a unique chance for unravelling the complexities of the volcanic system and interpreting the signals generated by deep magmatic and hydrothermal processes. Natural laboratory volcanoes like CFc provide a guide useful for comparisons as well as for expanding the range of possible interpretations of observations at other closed-conduit volcanoes in the world, to include likely mechanisms demonstrated elsewhere and improve the quality of volcanic hazards assessment and volcano behaviour forecasting.

Long data series collected at closed-conduit explosive volcanoes through sophisticated measurement techniques are necessary to understand the unrest dynamics, which is not only affected by the physico-chemical state of differentiated magmas intruded at shallow depths, but also by their interplay with gases released by deep magma sources. 


\section{Author contributions}

All authors contributed extensively to the work presented in this paper.

\section{Acknowledgements}

The authors thank Grant Heiken for his comments on the manuscript, which led to substantial improvements. Critical reviews by Bruno Scaillet and two anonymous reviewers have greatly improved the submitted manuscript. This work benefited from financial support from Projects INGV-DPC 2007-2009 V1 "UNREST", PRIN-MIUR 2009 and FP7-ENV 282759 “VUELCO”.

\section{Appendix A. Supporting information}

Supplementary data associated with this article can be found in the online version at http://dx.doi.org/10.1016/j.epsl.2013.02. 013.

\section{References}

Aiuppa, A., Moretti, R., Federico, C., Giudice, G., Gurrieri, S., Liuzzo, M., Papale, P., Shinohara, H., Valenza, M., 2007. Forecasting Etna eruptions by real-time observation of volcanic gas composition. Geology 35 (12), 1115-1118.

Aiuppa, A., Bertagnini, A., Métrich, N., Moretti, R., Di Muro, A., Liuzzo, M., Tamburello, G., 2010. A degassing model for Stromboli volcano. Earth Planet. Sci. Lett. 295, 195-204.

Allard, P., Maiorani, A., Tedesco, D., Cortecci, G., Turi, B., 1991. Isotopic study of the origin of sulfur and carbon in Solfatara fumaroles, Campi Flegrei caldera. J Volcanol. Geotherm. Res. 48, 139-159.

Arienzo, I., Moretti, R., Civetta, L., Orsi, G., Papale, P., 2010. The feeding system of Agnano-Monte Spina eruption Campi Flegrei (Italy): dragging the past into present activity and future scenarios. Chem. Geol. 270, 135-147.

Bachmann, O., Bergantz, G.W., 2006. Gas percolation in upper crustal silicic crysta mushes as a mechanism for upward heat advection and rejuvenation of nearsolidus magma bodies. J. Volcanol. Geotherm. Res. 149, 85-102.

Baker, D.R., Moretti, R., 2011. Modeling the solubility of sulfur in magmas: a 50year old geochemical challenge. Rev. Min. Geochem. 58, 167-213.

Belonoshko, A.B., Shi, P., Saxena, S.K., 1992. SUPERFLUID: a FORTRAN 77 program for calculation of Gibbs free energy and volume of $\mathrm{C}-\mathrm{H}-\mathrm{O}-\mathrm{N}-\mathrm{S}-\mathrm{Ar}$ mixtures. Comp. Geosci. 18, 1267-1269.

Berrino, G., 1994. Gravity changes induced by height-mass variations at the Campi Flegrei caldera. J. Volcanol. Geotherm. Res. 61, 293-309.

Caliro, S., Chiodini, G., Moretti, R., Avino, R., Granieri, D., Russo, M., Fiebig, J., 2007. The origin of the fumaroles of La Solfatara (Campi Flegrei, South Italy). Geochim. Cosmochim. Acta 71, 3040-3055.

Chiodini, G., Cioni, R., Magro, G., Marini, L., Panichi, C., Raco, B., Russo, M., 1996. Geochemical and isotopic variations of Bocca Grande fumaroles (Solfatara volcano, Phlegrean Fields). Acta Vulcanol. 8, 228-232.

Chiodini, G., Allard, P., Caliro, S., Parello, F., 2000. ${ }^{18} \mathrm{O}$ exchange between steam and carbon dioxide in volcanic and hydrothermal gases; implications for the source of water. Geochim. Cosmochim. Acta 64, 2479-2488.

Chiodini, G., Caliro, S., Caramanna, G., Granieri, D., Minopoli, C., Moretti, R. Perrotta, L., 2006. Geochemistry of the submarine gaseous emissions of Panarea (Aeolian Islands, Southern Italy): magmatic vs. hydrothermal origin and implications for volcanic surveillance. Pure Appl. Geophys. 163, 759-780.

Chiodini, G., Caliro, S., Cardellini, C., Granieri, D., Avino, R., Baldini, A., Donnini, M. Minopoli, C., 2010a. Long-term variations of the Campi Flegrei, Italy, volcanic system as revealed by the monitoring of hydrothermal activity. J. Geophys. Res. 115, B03205, http://dx.doi.org/10.1029/2008JB006258.

Chiodini, G., Avino, R., Caliro, S., Minopoli, C., 2011. Temperature and pressure gas geoindicators at the Solfatara fumaroles (Campi Flegrei). Ann. Geophys. 54, 2 , http://dx.doi.org/10.4401/ag-5002.

Chiodini, G., Caliro, S., De Martino, P., Gherardi, F., 2010b. Early signals of new volcanic unrest at Campi Flegrei caldera? Insights from geochemical data and physical simulations. Geology, 11, 004005, http://dx.doi.org/10.1130/G33251.1.

D’Auria, L., Giudicepietro, F., Aquino, I., Borriello, G., Del Gaudio, C., Lo Bascio, D. Martini, M., Ricciardi, G.P., Ricciolino, P., Ricco, C., 2011. Repeated fluid transfer episodes as a mechanism for the recent dynamics of Campi Flegrei caldera (19892010). J. Geophys. Res. 116, B04313, http://dx.doi.org/10.1029/2010JB007837.

D'Auria, L., Giudicepietro, F., Martini, M., Lanari, R., 2012. The 4D imaging of the source of round deformation at Campi Flegrei caldera (southern Italy). J. Geophys. Res. 117, B08209, http://dx.doi.org/10.1029/2012JB009181.

De Siena, L., Del Pezzo, E., Bianco, F., 2010. Seismic attenuation imaging of Campi Flegrei: evidence of gas reservoirs, hydrothermal basins, and feeding systems. J. Geophys. Res. 115, B09312, http://dx.doi.org/10.1029/2009JB006938.
Di Renzo, V., Arienzo, I., Civetta, L., D’Antonio, M., Tonarini, S., Di Vito, M.A., Orsi, G., 2011. The magmatic feeding system of the Campi Flegrei caldera: architecture and temporal evolution. Chem. Geol. 281, 227-241.

Edmonds, M., Aiuppa, A., Humphreys, M., Moretti, R., Giudice, G., Martin, R., Herd, R.A., Christopher, T., 2012. Excess volatiles supplied by mingling of mafic magma at an andesitic arc volcano. Geophys. Geochem. Geosyst. 40, 943-946.

Fabbrizio, A., Scaillet, B., Carroll, M.R., 2009. Estimation of pre-eruptive magmatic water fugacity in the Phlegrean Fields, Naples, Italy. Eur. J. Mineral. 21, 27-116.

Giggenbach, W.F., 1987. Redox processes governing the chemistry of fumarolic gas discharges from White Island New Zealand. Appl. Geochem. 2, 143-161.

Giggenbach, W.F., 1996. Chemical composition of volcanic gases. In: Scarpa, R., Tilling, R.I. (Eds.), Monitoring and Mitigation of Volcano Hazards. Springer, New York, pp. 202-226.

Gottsmann, J., Folch, A., Rymer, H., 2006. Unrest and Campi Flegrei: a contribution to the magmatic versus hydrothermal debate from inverse and finite element modeling. J. Geophys. Res. 111, B07203, http://dx.doi:org/10.10292005JB003745.

Heidemann, R., Khalil, A., 1980. The calculation of critical points. AIChe J. 26, 769.

Hoefs, J., 2004. Stable Isotope Geochemistry. Springer-Verlag, Berlin Heidelberg. (201 pp.).

Holloway, J.R., Blank, J.G., 1994. Application of experimental results to C-O-H species in natural melts. Rev. Mineral. 30, 187-230.

Lasaga, A., 1998. Kinetic Theory in the Earth Sciences. Princeton University Press, Princeton.

Longo, A., Vassalli, M., Papale, P., Barsanti, M., 2006. Numerical simulation of convection and mixing in magma chambers replenished with $\mathrm{CO}_{2}$-rich magma. Geophys. Res. Lett. 33, L21305, http://dx.doi.org/10.1029/2006GL027760.

Mangiacapra, A., Moretti, R., Rutherford, M., Civetta, L., Orsi, G., Papale, P., 2008. The deep magmatic system of the Campi Flegrei caldera (Italy). Geophys. Res. Lett. 35, L21304, http://dx.doi.org/10.1029/2008GL035550.

Marini, L., Moretti, R., Accornero, M., 2011. Sulfur isotopes in magmatic-hydrothermal systems, melts, and magmas. Rev. Mineral. Geochem. 73, 423-492.

Maddox, R., Lilly, L., 1990. Gas Conditioning and Processing, vol. 3, Computer Applications and Production/Processing Facilities. Campbell Petroleum Series.

Michelsen, M., Heidemann, R., 1981. Calculation of critical points from cubic twoconstant equation of state. AIChE J., 27.

Moretti, R., 2005. Polymerisation, basicity, oxidation state and their role in ionic modelling of silicate melts. Ann. Geophys. 48, 583-608.

Moretti, R., Papale, P., Ottonello, G., 2003. A model for the saturation of C-H-O-S fluids in silicate melts. In: Oppenheimer, C., Pyle, D.M., Barclay, J. (Eds.), Volcanic Degassing, 213. Geological Society London Special Publication, pp. 81-101.

Moretti, R., Papale, P., 2004. On the oxidation state and volatile behavior in multicomponent gas-melt equilibria. Chem. Geol. 213, 265-280.

Moretti, R., Ottonello, G., 2005. Solubility and speciation of sulfur in silicate melts: the Conjugated-Toop-Samis-Flood-Grjotheim (CTSFG) model. Geochim. Cosmochim. Acta 69, 801-823.

Moretti, R., Baker, D.R., 2008. Modeling of the interplay of $\mathrm{fO}_{2}$ and $\mathrm{fS}_{2}$ along the FeS-Silicate Melt equilibrium. Chem. Geol. 256, 286-298.

Moretti, R., Arienzo, I., Civetta, L., Orsi, G., D'Antonio, M.The deep plumbing system of the Ischia island: a physico-chemical window on the fluid-saturated and $\mathrm{CO}_{2}$-sustained Neapolitan volcanism (Southern Italy). J. Petrol., http://dx.doi. org/10.1093/petrology/egt002, in press.

Mormone, A., Piochi, M., Bellatreccia, F., De Astis, G., Moretti, R., Della Ventura, G. Cavallo, A., Mangiacapra, A., 2011. A $\mathrm{CO}_{2}$-rich magma source beneath the Phlegraean Volcanic District (Southern Italy): evidence from a melt inclusion study. Chem. Geol. 287, 66-80.

Newhall, C.G., Dzurisin, D., 1988. Historical unrest at large calderas of the world. U.S. Geological Survey Bulletin, 2nd vol.

Oppenheimer, C., Moretti, R., Kyle, P., Eschenbacher, A., Lowenstern, J., Hervig, G, Dunbar, N., 2011. Mantle to surface gas trigger of the alkalic intraplate Erebus volcano, Antarctica. Earth Planet. Sci. Lett. 306, 261-271.

Orsi, G., de Vita, S., Di Vito, M.A., 1996. The restless, resurgent Campi Flegrei nested caldera (Italy): constraints on its evolution and configuration. J. Volcanol. Geotherm. Res. 74, 179-214.

Orsi, G., Civetta, L., Del Gaudio, C., de Vita, S., Di Vito, M.A., Isaia, R., Petrazzuoli, S., Ricciardi, G., Ricco, C., 1999. Short-term ground deformations and seismicity in the nested Campi Flegrei caldera (Italy): an example of active block resurgence in a densely populated area. J. Volcanol. Geotherm. Res. 91, 415-451.

Orsi, G., Di Vito, M.A., Isaia, R., 2004. Volcanic hazard assessment at the restless Campi Flegrei caldera. Bull. Volcanol. 66, 514-530.

Orsi, G., Di Vito, M.A., Selva, J., Marzocchi, W., 2009. Long-term forecast of eruption style and size at Campi Flegrei caldera (Italy). Earth Planet. Sci. Lett. 287, 265-276.

Parfitt, E.A., Wilson, L., 2008. Fundamentals of Physical Volcanology. Blackwell Publishing, Oxford.

Papale, P., Moretti, R., Barbato, D., 2006. The compositional dependence of the saturation surface of $\mathrm{H}_{2} \mathrm{O}+\mathrm{CO}_{2}$ fluids in silicate melts. Chem. Geol. 229, 78-95.

Peluso, F., Arienzo, I., 2007. Experimental determination of permeability of Neapolitan Yellow Tuff. J. Volcanol. Geotherm. Res. 160, 125-136.

Richet, P., Bottinga, Y., Javoy, M., 1977. A review of $\mathrm{H}, \mathrm{C}, \mathrm{N}, \mathrm{O}, \mathrm{S}$ and $\mathrm{Cl}$ stable isotope fractionation among gaseous molecules. Annu. Rev. Earth Planet. Sci. Lett. 5, 65-110.

Roach, A.L., 2005. The Evolution of Silicic Magmatism in the Post-Caldera Volcanism of the Phlegrean Fields, Italy. Ph.D. Thesis. Brown University.

Selva, J., Orsi, G., Di Vito, M.A., Marzocchi, W., Sandri, L., 2012. Probability hazard map for future vent opening at the Campi Flegrei caldera, Italy. Bull. Volcanol. 74, 497-510. 
Shinohara, H., 2008. Excess degassing from volcanoes and its role on eruptive and intrusive activity. Rev. Geophys. 46, RG4005.

Symonds, R.B., Gerlach, T.M., Reed, M.H., 1991. Magmatic gas scrubbing: implication for volcano monitoring. J. Volcanol. Geotherm. Res. 108, 303-341.

Todesco, M., Berrino, G., 2005. Modeling hydrothermal fluid circulation and gravity signals at the Phlegraean Fields caldera. Earth Planet. Sci. Lett. 240, 328-338.

Todesco, M., Rinaldi, A.P., Bonafede, M., 2010. Modeling of unrest signals in heterogeneous hydrothermal systems. J. Geophys, Res. 115, B09213, http://d X.doi.org/10.1029/2010JB007474.

Trasatti, E., Bonafede, M., Ferrari, C., Giunchi, C., Berrino, G., 2011. On deformation sources in volcanic areas: modeling the Campi Flegrei (Italy) 1982-84 unrest. Earth Planet. Sci. Lett. 306, 175-185.

Turi, B., Taylor, J.H.P., Ferrara, G., 1991. Comparison of ${ }^{18} \mathrm{O} /{ }^{16} \mathrm{O}$ and ${ }^{87} \mathrm{Sr} /{ }^{86} \mathrm{Sr}$ in volcanic rocks from the Pontine Islands, M. Ernici, and Campania with other areas of Italy. In: Taylor, H.P., O’Neil, J.R., Kaplan, I.R. (Eds.), Stable Isotope Geochemistry: A tribute to Samuel Epstein, vol. 3. Geochemical Society Special Publication, pp. 307-324.

Woo, J.Y.L., Kilburn, C.R.J., 2010. Intrusion and deformation at Campi Flegrei, southern Italy: sills, dikes, and regional extension. J. Geophys. Res. 115, B12210, http://dx.doi.org/10.1029/2009JB006913.

Zhao, Z.-F., Zheng, Y.-F., 2003. Calculation of oxygen isotope fractionation in magmatic rocks. Chem. Geol. 193, 59-80.

Zheng, Y.F., 1993. Calculation of oxygen isotope fractionation in anhydrous silicate minerals. Geochim. Cosmochim. Acta 57, 1079-1091.

Zollo, A., Maercklin, N., Vassallo, M., Dello Iacono, D., Virieux, J., Gasparini, P., 2008 Seismic reflections reveal a massive melt layer under Campi Flegrei volcanic field. Geophys. Res. Lett. 35, L12306, http://dx.doi.org/10.1029/2008GL034242. 